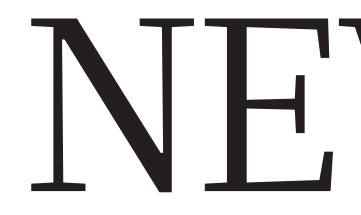

MEDICINE UK health service takes cancer-gene testing nationwide $\mathbf{p . 7 6 6}$
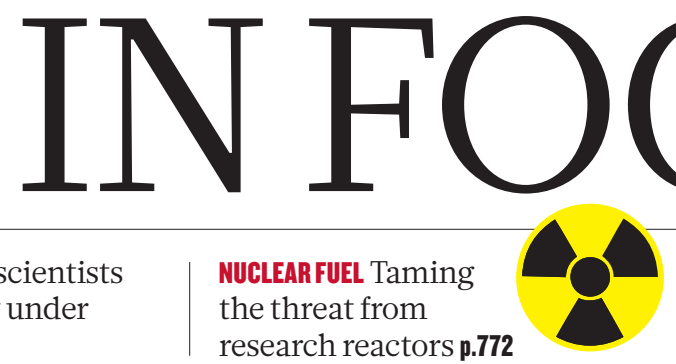

NUCLEAR FUEL Taming the threat from research reactors $\mathbf{p . 7 7 2}$
coMmunity Can US scientists speak more freely under Obama? p.768
SkILLS What scientists don't know about computer programming $\mathbf{p . 7 7 5}$

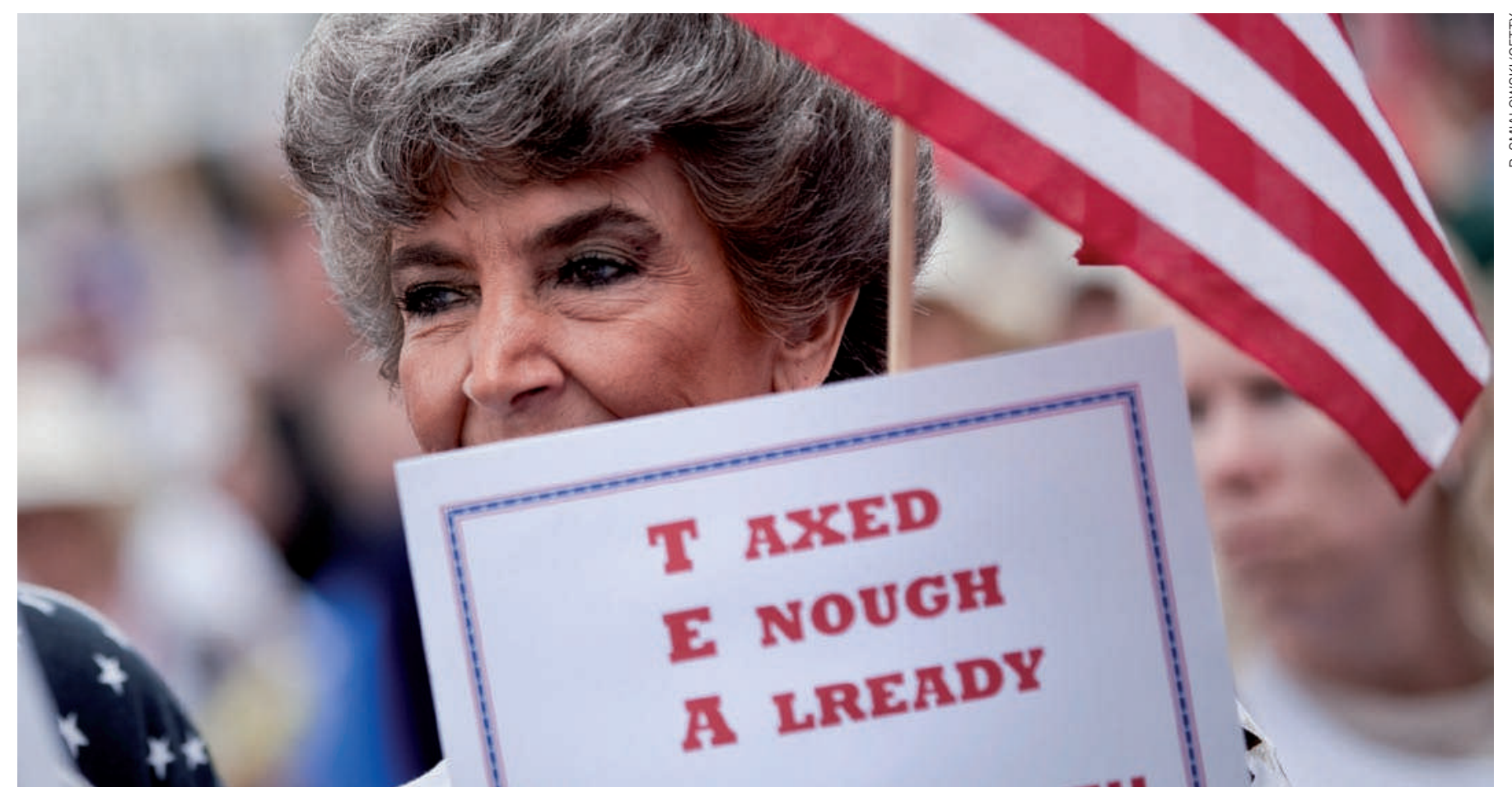

US MIDTERM ELECTIONS

\title{
Volatile forces shape US vote
}

\section{Science could face budget constraints and ideological challenges in a post-midterm Congress.}

\section{BY IVAN SEMENIUK}

"W ant to cap Congress - not carbon?" The question appeared, slogan-style, in an online notice urging Virginia voters to attend a Tea Party convention held last week in the state's capital, Richmond. Organizers say that more than 2,800 people attended the event, the largest meeting yet for the new political movement that is injecting an unusual degree of volatility into this year's US midterm-election season.

Strong opposition to greenhouse-gas regulation is just one manifestation of a broader Tea Party theme: keeping government small. Now the Tea Party phenomenon (and the public ire it has tapped) has become the defining feature of a campaign that will determine who, on
2 November, occupies each seat in the House of Representatives and more than one-third of the seats in the Senate. With Democrats currently holding narrow majorities in both chambers, even a modest change at the polls could spell a wholesale transfer of power in Congress and a seismic shift in the US political landscape. The governorships of 37 states are also in play this year, including that of California, a research powerhouse. It is difficult to predict how all this will affect scientists and the government agencies that fund them, but with the US economy staggering under the burden of high unemployment and record-setting federal deficits, the new Congress, whatever its ideological bent, will preside over diminished resources and difficult choices.

"In the face of fiscal constraints to come, making decisions on where to cut and how that will affect our research and innovation effort is a very serious issue," says Anne Solomon, a senior adviser on science and technology at the Center for the Study of the Presidency and Congress, a think tank based in Washington DC.

An issue paper co-authored this year by Solomon calls for a "science and technologyenhanced Congress", in which legislators are broadly knowledgeable about science and have better access to technical expertise on the complex issues they face - from energy policy, to education, to economic and security matters. In fact, the opposite is likely to be true of the next Congress.

Several senior figures who are strong on science policy are retiring, or may be ousted in a Tea Party-boosted vote swing. Solomon worries that this could mean an influx of new players on Capitol Hill who are less committed to 
- funding science research and education, and who lack "the general science and technology savvy" to make informed decisions.

The Tea Party's conservative message could also affect how science is treated in Congress. Last week's convention in Richmond featured appearances by politicians including former Pennsylvania senator Rick Santorum, who once tried to amend an education bill to promote the teaching of intelligent design, and Virginia attorney general Ken Cuccinelli, who recently renewed his efforts to investigate and discredit climate scientist Michael Mann, formerly at the University of Virginia in Charlottesville.

But the Tea Party's biggest influence stems from its small-government, costcutting agenda. This has been taken on board by the Republicans, who are currently leading in the polls and look set to win the House from their Democratic rivals. The Republicans' 45-page policy document, unveiled on 23 September, is telling in both its emphasis and its omissions. Although the words "tax", "taxes" and "taxpayer" appear 56 times in the document, the words "science", "research" and "education" do not figure once.

In the current Democrat-controlled Congress, science was given plenty of attention in spite of the economic crisis. The National Science Foundation and the National Institutes of Health received influxes of cash as part of President Barack Obama's economic stimulus package. Legislation such as the health-care reform bill and a bill to deal with oil spills (not yet passed by the Senate) also include provisions for funding research and development. Disputes between the parties on science spending have tended to be "differences of opinion on how much to invest in basic research, not on whether or not it was important", says Joanne Carney, director of the Center for Science, Technology and Congress at the American Association for the Advancement of Science in Washington DC.

In his inaugural address, Obama promised to "restore science to its rightful place", and he appointed prominent researchers and science-policy experts to key government roles. But as the stories on the following pages detail, science faces plenty of challenges for the post-midterm Congress to address.

And given the changing political climate, the new Congress looks likely to be even more polarized than the last. If Republicans are running the House, the Obama administration will be dealing with an adversary rather than an ally as it tries to push through changes in areas such as energy and education. As concerns about the deficit combine with an enthusiasm for scaling back government, science funding could see heavy reductions. @ SEE EDITORIALP.75I

US MIDTERM ELECTIONS

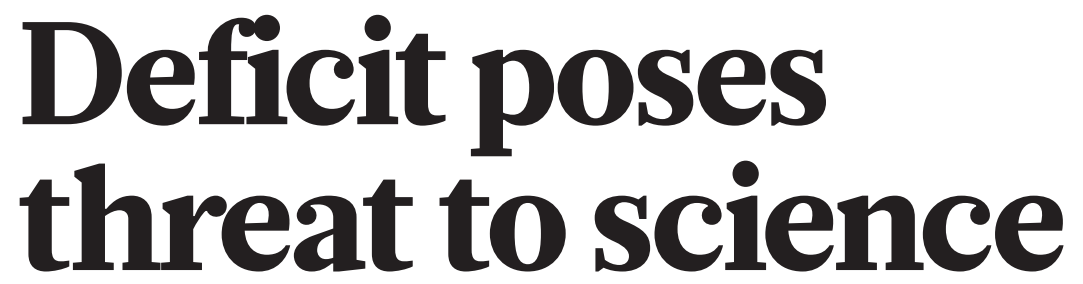

\section{Research programmes in the United States seem to be heading for a cliff, no matter who wins in Congress.}

\section{BY EUGENIE SAMUEL REICH}

U nlike their counterparts elsewhere, US scientists have been sitting pretty in the wake of the global economic downturn. The 2009 American Recovery and Reinvestment Act, or stimulus bill, pumped an extra US $\$ 31$ billion into science, and President Barack Obama's budget request for fiscal year 2011 included generous increases for several science-funding agencies.

But going into the midterm elections, a different narrative is emerging. Republicans are running on a platform to reduce the \$1.4-trillion US deficit, which seems likely to entail freezes or effective cuts for at least some science programmes. If the Democrats retain control of Congress by a thin margin, policy experts say that they are likely to interpret the loss of seats as a call to rein in spending too. "Science is pretty well supported by both sides, but it's a matter of balancing investment with the deficit," says Patrick Clemins, director of the research and development budget and policy programme at the American Association for the Advancement of Science in Washington DC.

A Republican win would probably spell problems for America COMPETES, a 2007 act of Congress that set the National Science Foundation (NSF), the National Institute of Standards and Technology and the Department of Energy's Office of Science on a path to double their funding over ten years. America COMPETES originally passed with bipartisan support, and stimulus funding provided

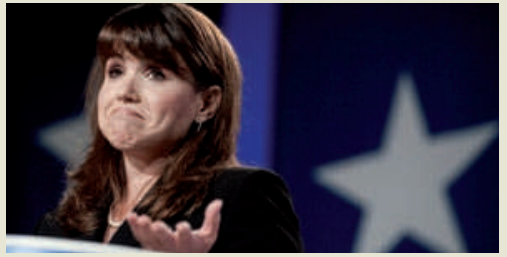

STATE WATCH: DELAWARE

Having defeated high-profile moderate Republican Michael Castle in her state's primary campaign, Tea Partyendorsed Delaware Senate candidate Christine O'Donnell (pictured) now faces scrutiny over some of her public statements, including a 2007 assertion that "American scientific companies are cross-breeding humans and animals and coming up with mice with fully functioning human brains". She has also called evolution a myth and opposes stem-cell science. O'Donnell's election race against Democrat Christopher Coons may serve as a barometer for how far US voters will tolerate views unfriendly to science from the resurgent right.

a further boost for research in 2009. But COMPETES expired at the end of September 2010 because Republicans objected to its high funding levels and slowed the passage of its reauthorization. Even if COMPETES passes

\section{FEDERAL FUNDS FOR RESEARCH}

US science spending has changed only gradually over the past 25 years, regardless of the party in power.

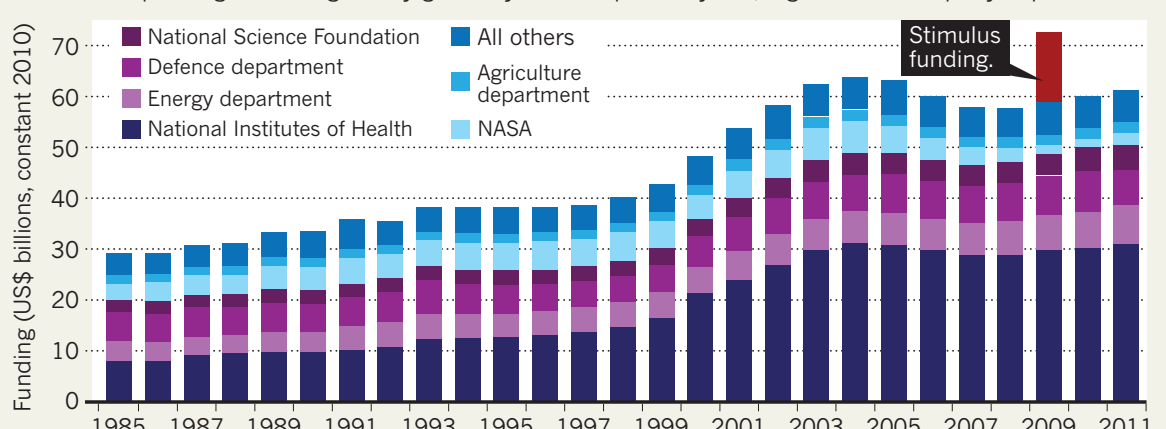

